\title{
Influence of landscape properties on stream water quality in agricultural catchments in Southeastern Brazil
}

\author{
Gisele Biem Mori ${ }^{1 *}$, Felipe Rossetti de Paula ${ }^{1}$, Silvio Frosini de Barros Ferraz ${ }^{2}$, \\ Antonio Fernando Monteiro Camargo ${ }^{1}$ and Luiz Antônio Martinelli ${ }^{3}$ \\ 1 Departamento de Ecologia, Universidade Estadual Paulista “Júlio de Mesquita Filho" -UNESP, Campus de Rio Claro, Av. 24 A, \\ 1515, Rio Claro, SP, Brazil \\ 2 Departamento de Ciências Florestais - Escola Superior de Agricultura “Luiz de Queiroz”, ESALQ, Av. Pádua Dias, 11, Piracicaba, \\ SP, Brazil \\ 3 Centro de Energia Nuclear na Agricultura, CENA, Av. Centenário, 303, Piracicaba, SP, Brazil
}

Received 27 October 2013; Accepted 5 August 2014

\begin{abstract}
Changes in land cover, especially the replacement of forest by agricultural activities affect the hydrological processes of river catchments, resulting in physical and chemical compositional changes of water draining from affected basins. The aim of this study was to evaluate landscape influences at different spatial scales (catchment and riparian) on the physical and chemical composition of stream water in 15 agricultural catchments, belonging to the Corumbataí basin (Brazil). We calculated the average slope (\%), average elevation $(\mathrm{m})$, soil classes $(\%)$, major land use classes $(\%)$, average distance from the forest cover in relation to the hydrographic network $(\mathrm{m})$, largest patch index $(\%)$ at the catchment scale and riparian zone of drainage network scale within a $30 \mathrm{~m}$ buffer. Water samples were collected in two seasons (dry and rainy) to characterize physical and chemical properties: turbidity, suspended solids, total nitrogen, nitrate and total phosphorus. Our results showed higher concentration of nitrate in sugarcane fields and larger amount of suspended solids and turbidity in pasture areas. We concluded that degraded and highly fragmented forests may not be effectively contributing toward the protection of aquatic ecosystems.
\end{abstract}

Key words: Landscape ecology / land use / limnology / conservation of forests and aquatic ecosystems

\section{Introduction}

The properties of stream water respond directly to land cover changes in the catchments which they drain (Johnson et al., 1997; Storey and Cowley, 1997; Park et al., 2011). For this reason, changes in the forest cover of a catchment exert influence on the physical and chemical characteristics of water bodies, affecting the natural hydrological and ecological processes that occur in the aquatic environment (Ziemer and Lisle, 1998; Allan and Castillo, 2007).

Forest cover acts in different ways to conserve aquatic ecosystems, especially in areas close to water bodies. These areas are characterized as a transition zone between aquatic and terrestrial ecosystems and are thus essential for the maintenance and conservation of aquatic ecosystem and limnological characteristics of the water (Naiman

*Corresponding author: giselebiem@gmail.com and Décamps, 1997; Naiman et al., 2005). Riparian forests play a crucial role for ecological functions such as nutrient cycling, hydrological regulation, food and shelter provisioning for the aquatic fauna, maintenance of the microclimate and energy flow (Gregory et al., 1991; Naiman and Décamps, 1997; Naiman et al., 2005), stabilization of banks (Allmendinger et al., 2005) and filtration of nutrients and materials from the surrounding areas (Wenger, 1999; Bicalho et al., 2010).

The removal of forests to establish pasture or crops causes exposure to the diverse changes generated by agricultural expansion (Johnson et al., 1997; Hunter and Walton, 2008). This includes the release of chemicals into water bodies, soil erosion and the reduction of riparian areas (Johnson et al., 1997; Hunter and Walton, 2008).

The Corumbataí River Basin is located in an area of intensive economic development in the State of São Paulo (Brazil), with a long history of land use and occupation. (Victor et al., 2005) Thus, its landscape consists of a matrix 

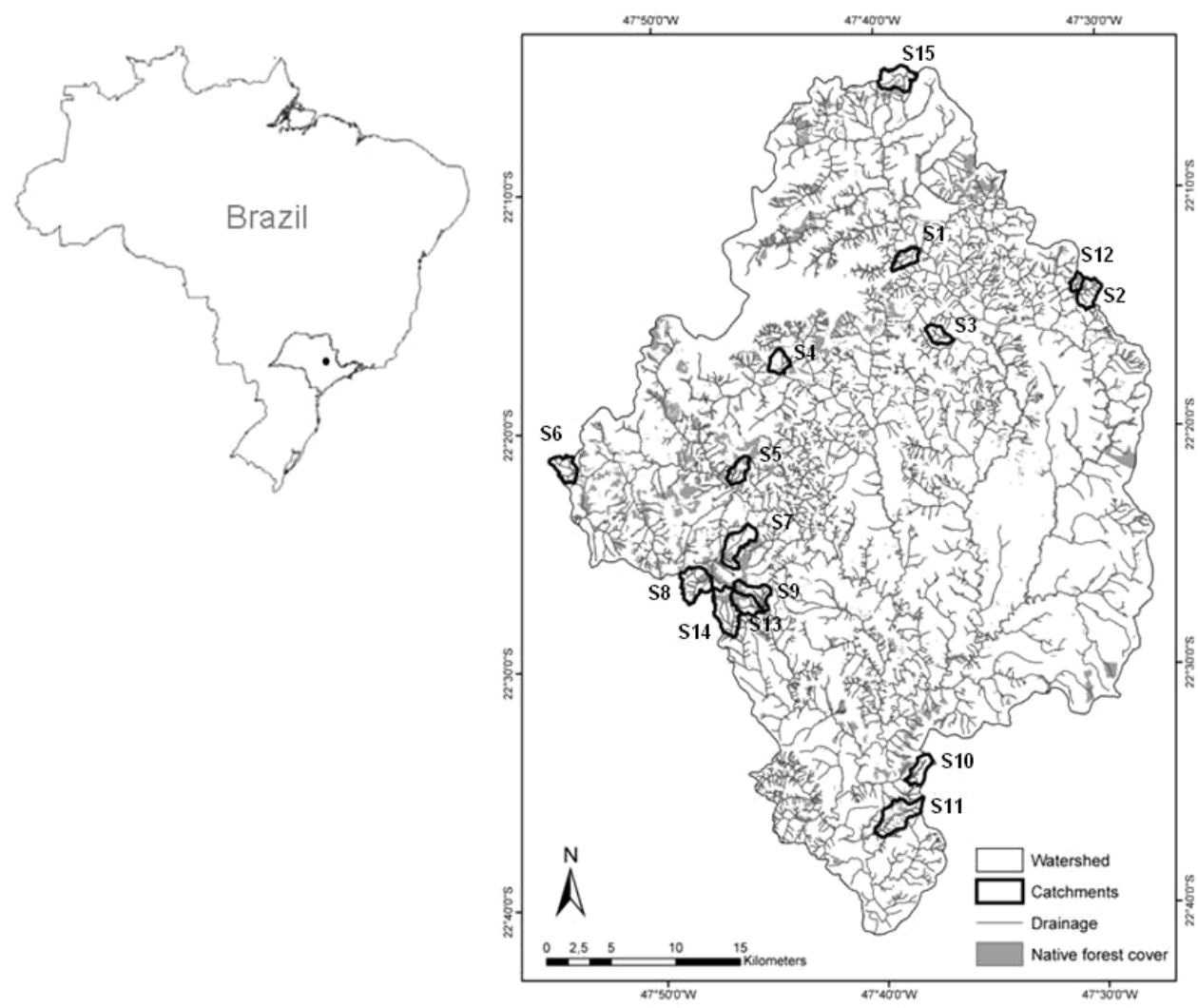

Fig. 1. Location of the studied catchments in the Corumbataí river basin, São Paulo state, Brazil.

of agricultural uses (pasture and sugarcane) (Valente and Vettorazzi, 2003) and in many cases the remaining forests are very fragmented and degraded (Rodrigues, 1999; Valente and Vettorazzi, 2005). Owing to the remaining forests are degraded, their functions for the protection and conservation of water and aquatic ecosystems may be substantially decreased. In this study, we evaluated the influence of the landscape at different spatial scales (catchment and riparian zone) on the physical and chemical composition of stream water in agricultural catchments. Our hypothesis is that changes in the forest cover configuration (reduction and fragmentation) due to agricultural activities increase the input of nutrients and sediments to the stream water. The specific objectives were: (1) to evaluate whether water quality differ among catchments with pasture, sugar cane and forest cover by increasing nutrient and sediment input into the stream water; (2) to evaluate the relationships between water characteristics and landscape structure variables.

\section{Material and methods}

\section{Study area}

The study was conducted in 15 catchments in the Corumbataí river basin (areas ranging from 98 to 600 ha, Fig. 1), as a sub-basin of the Piracicaba river basin. It is located in the state of São Paulo and covers an area of
$171 \mathrm{~km}^{2}$. The region has a sub-tropical climate of type "Cwa" (Köppen), i.e., with rainy summers and dry winters, with over $80 \%$ of annual rainfall occurring from October to February, and only $20 \%$ during March to September (Valente and Vettorazzi, 2008). The main river in the region is the Corumbataí, which has its headwaters in the city of Analândia and flows into the Piracicaba river. The Corumbataí river has three main tributaries: the Cabeça, Passa-cinco and Ribeirão Claro rivers. The predominant soil types in the region are Nitisols $(44 \%)$ and Ferralsols (22\%) (Valente and Vettorazzi, 2008).

Originally, the Corumbataí river basin was a heterogeneous landscape predominantly composed of deciduous forest, semideciduous forest, riparian forest, savanna and swamp forests (Rodrigues, 1999). Deforestation in the basin began with the introduction of coffee cultivation and subsistence farming in the early 18 th century with areas cleared for these purposes and subsequently replaced by pastures (Victor et al., 2005; CEAPLA, 2008). More recently, sugarcane cultivation expanded (Valente and Vettorazzi, 2003). With this intensive deforestation process, the remaining forest cover is highly fragmented and poorly conserved, largely restricted to steep slopes and isolated forest stretches next to water bodies. Currently, land use in the Corumbataí basin consists mainly of pasture and sugarcane plantation (Valente and Vettorazzi, 2003), comprising 44 and $26 \%$ total basin area, respectively. Native forests cover only $11 \%$ of the basin area (Valente and Vettorazzi, 2005). 


\section{Landscape characteristics of the catchments}

Maps of land use, hydrography and catchment limits were obtained from Paula et al. (2011) using topographic maps (1:10000, year 1979, Cartographic and Geographic Institute of the State of São Paulo) and aerial photographs (scale 1:30000, year 2000). Maps were derived using the software ArcGIS 9.2. For this work we considered only the main categories of land use: pasture, sugarcane and forest. The soil map used in the study was provided by the Center for Environmental Analysis and Planning (CEAPLA), Institute of Geosciences and Exact Sciences of São Paulo State University, campus Rio Claro. Catchment characterization was based on the calculation of physical and landscape variables.

Physical variables included slope, elevation and the proportion of predominant soil classes. In order to extract the physical attributes of each catchment (elevation and slope), a digital elevation model (DEM) was generated from contour lines (5 m interval) using a Triangulated Irregular Network (TIN) model. The proportion of soil classes was obtained from map of soil classes. Landscape structure variables included the proportion of land use classes (extracted from the land use map), mean distance of forest to streams (DFS) and largest patch index. The calculation of average distance from the forest cover in relation to the hydrographic network was carried out in two steps. Initially, a surface distance (grid) in relation to streams was obtained. Subsequently, an overlay was performed using the distance surface and the land use maps to obtain average distance of the forest in relation to hydrography. The largest patch index was obtained by dividing the area of the largest forest fragment by the total area of catchment considered and multiplying the value obtained by 100 (McGarigal et al., 2002). These variables were obtained at the scale of the catchment and riparian zone (except average distance from the forest to the river network) using ArcGIS 9.2 (Environmental Systems Research Institute, Redlands, CA, USA) and Fragstats 3.3 (McGarigal et al., 2002). To calculate the metrics at the drainage network scale, a $30 \mathrm{~m}$ buffer zone (minimum distance set by the current Brazilian Forest Code) around the river network was generated.

\section{Sampling}

Water samples were collected during two seasons in year 2008, one in February (rainy season) and one in July (dry season). Samples were collected at pre-selected points (downstream) of the catchments under study, being a collection in each watershed. The field sites were located using a handheld computer Mio P550 and ArcPad 7.0 software. Turbidity measurements were obtained using a "Water Quality Checker" (Horiba, model U-10). A general characterization of the river channel at the collection points was also made (channel width and depth) using measuring tapes. Water samples were collected and stored in 1.0 and $0.5 \mathrm{~L}$ polyethylene bottles and kept at $10{ }^{\circ} \mathrm{C}$ during transportation to the laboratory. Subsequently, samples were thawed and the concentrations of total Kjeldahl nitrogen and N-nitrate were obtained following Mackereth et al. (1978) and total phosphorus following Golterman et al. (1978). To determine the suspended material previously weighed filters of $0.45 \mu \mathrm{m}$ were used. Water samples $(1 \mathrm{~L})$ were filtered with a vacuum pump and the filters were placed in an oven $(24 \mathrm{~h})$ and weighed. The amount of suspended material was obtained from the difference between the final and initial dry masses.

\section{Data analysis}

Differences in the physical and chemical characteristics of the water samples were tested in relation to predominant land use and land cover at the scale of catchment and riparian zone. The variables analyzed are shown in Table 1. To define groups of river catchments according to the predominant use in each spatial scale, we performed a cluster analysis using the proportion of forest use, sugarcane and pasture as variable. Cluster analysis was performed using Pearson's distance as a measure of similarity and the un-weighted pair-group method using arithmetic averages (UPGMA) as the connection method (McGarigal et al., 2002). To define the number of clusters to be interpreted, the level at which each dendrogram should be cut was defined using silhouette widths (Borcard et al., 2011). At each fusion level, silhouette width was computed to measure the intensity of the link of the objects to their groups. Silhouette widths range from -1 to 1 , and the best number of clusters is that with the largest average silhouette width (Borcard et al., 2011).

Exploratory analysis (scatter plots and correlations) was used to assess data normality, linearity of relationships among variables and the presence of extreme data (outliers). Non-normal data were transformed to improve normality and linearity of relationships, as well as to downweight the influence of outliers. $\log _{10}$ transformation was applied for variables with a positive skewed distribution and arcsine transformation was applied for the variables of proportion (Table 1) (Zar, 1996; Quinn and Keough, 2002). Graphical biplots from principal component analysis (PCA) were used to evaluate the formation of catchment groups generated by cluster analysis and to evaluate the relationships between limnological variables of the water and the proportions of the major land uses. For this analysis, the variables were standardized in the same scale from a correlation matrix (Quinn and Keough, 2002).

Catchment groups for riparian scale were defined from the biplots and dendrogram. As the groups for catchment scale were not consistent in both analyses we separate them in two groups: agriculture ( $<40 \%$ of forest) and mix of uses ( $\geq 40 \%$ of forest). These groups were considered to the ANOVA tests (Quinn and Keough, 2002). MannWhitney tests were used for the variables that present residuals with non-normal distribution (Zar, 1996).

Multiple linear regression was used to evaluate the relationship between the water variables (response 
Table 1. Water and landscape variables considered in the present study. Abbreviation code, units and statistical transformation are shown.

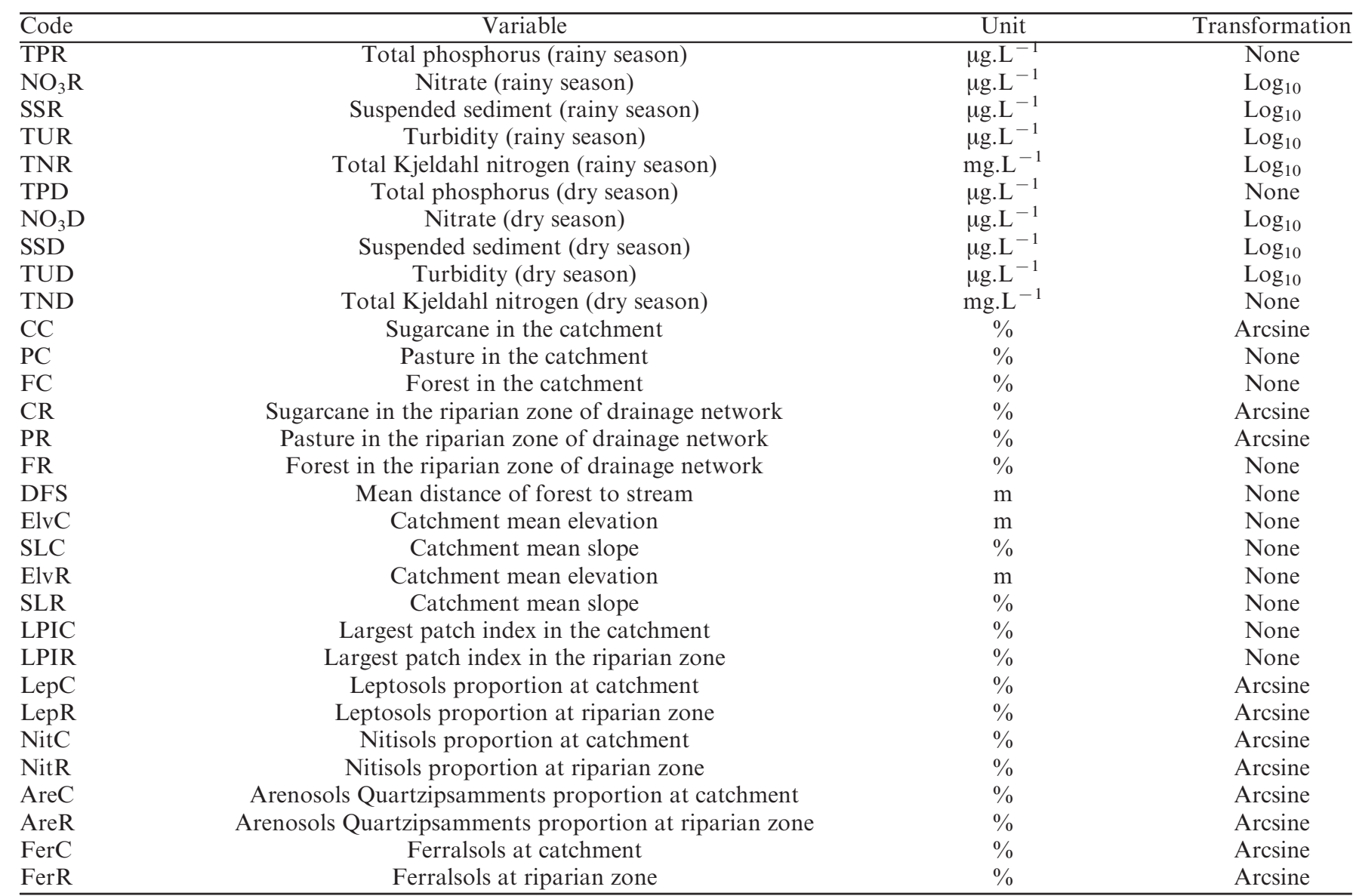

variables) and landscape structure and the soil classes (independent variables) considering the two spatial scales and two seasons (rainy and dry). Prior to carrying out the regression analysis, the predictor variables were standardized to the same average scale (zero mean and standard deviation of one - Quinn and Keough, 2002). Forward selection was performed to select the best variables in the models (Legendre and Legendre, 2000; Crawley, 2007). Validity of the regression analysis was assessed by analyzing model residuals graphically (plots of residuals against fitted values; Quinn and Keough, 2002) and statistically (Shapiro test for the normality of the residuals).

Statistical analysis was performed using R (R Development Core Team, 2008) and the $P<0.05$ level.

\section{Results}

The predominant land use at the catchment scale was pasture, except for S6 and S10 (mainly sugarcane) and S11 (mainly forest; Fig. 2). On the other hand, there was a predominance of forest at the riparian scale, except for S1, S4, S7 and S15, which exhibit a predominance of pasture, while sugarcane does not predominate any of the streams at this spatial scale (30 m buffer; Fig. 2).
The dendrogram generated by cluster analysis was cut at the fusion level to obtain three groups at the catchment scale (silhouette width $=0.48$ ) and two groups at the riparian scale (silhouette width $=0.50$; Fig. 3). At the catchment scale, eight sites formed a group dominated by pasture, while only three sites were representative for sugarcane and four sites were grouped to represent both, a predominance of pasture and forest (with a dissimilarity threshold of 1.7). At the riparian scale, five sites formed a group dominated by pasture, while other ten sites formed a group characterized by a predominance of forest (with a dissimilarity threshold of 2.5).

The biplots from PCA revealed a more refined pattern generated by cluster analysis at the catchment scale (Fig. 4(A) and Table 2). However, there was some overlap among groups showing that in several basins there is no dominant land use at this spatial scale. At the riparian scale (Fig. 4(B) and Table 2) there was a clear separation of groups similar to those generated by cluster analysis, with the biplot showing a dominance of pasture and forest at this spatial scale.

The results of the ANOVA and the Mann-Whitney tests show no difference in mean values for the variables evaluated, except for nitrate, that were higher in agriculture groups. At the catchment scale, the difference in 


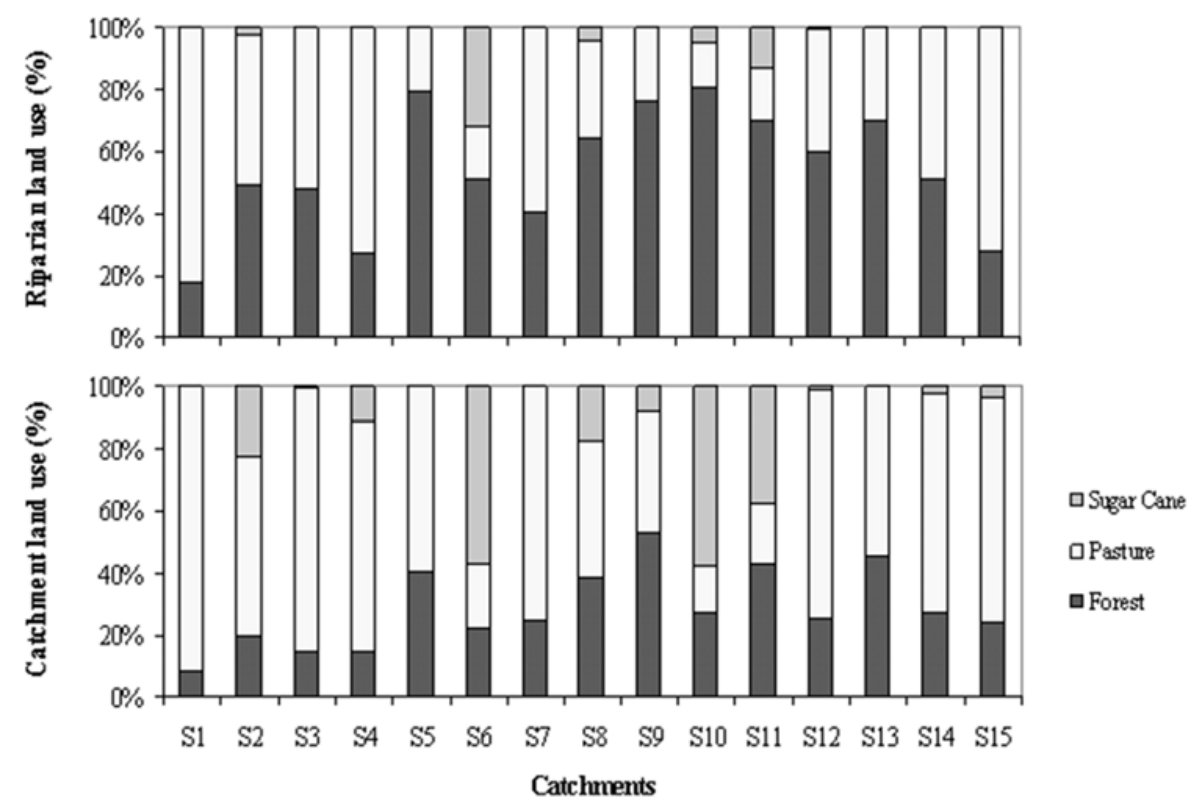

Fig. 2. Distribution of main categories of land use in catchment and riparian zone scales.
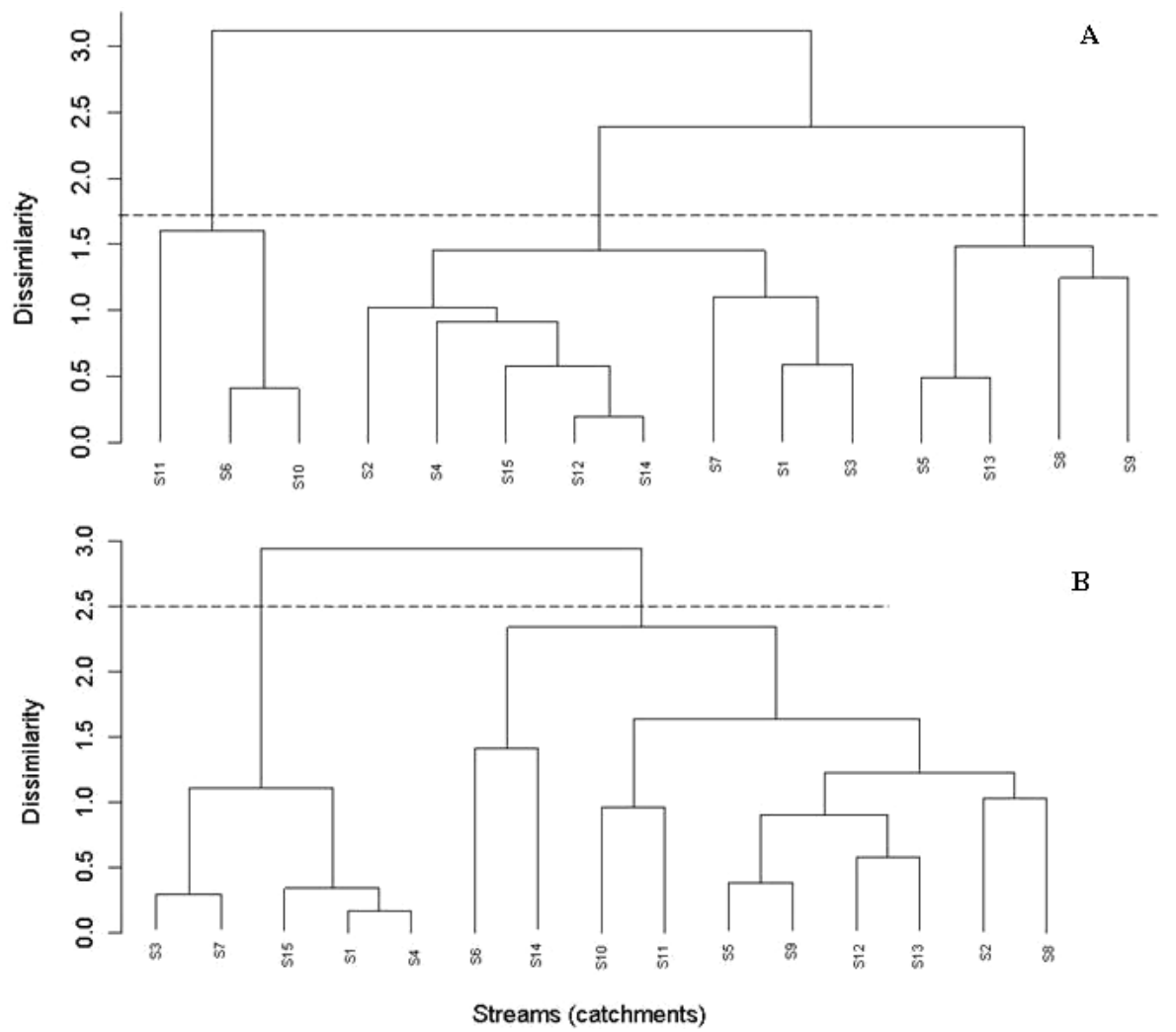

Fig. 3. Catchments clusters considering the dominant land uses categories at catchment (A) and riparian-zone (B) scales.

nitrate concentration was significant in the dry season, whereas this difference was significant in both seasons at the riparian scale.

For both scales evaluated, results showed that the relationships between water variables and the proportions of land use are very similar (Fig. 4(A) and Table 2). The nitrate variable (in both seasons) showed a positive relationship with the proportions of sugarcane and forest land use and a negative relationship with the proportion of pasture at both scales (catchment and riparian). The total nitrogen in the rainy season showed a weak inverse relationship with the proportion of sugarcane and a positive relationship with the proportion of pasture at both scales. Turbidity in both seasons had an inverse 
Table 2. PCA analyses. Total phosphorus in rainy (TPR) and dry season (TPD); total Kjeldahl nitrogen in rainy (TNR) and dry season (TND); nitrate in rainy (NO3R) and dry season (NO3D); suspended sediment in rainy (SSR) and dry season (SSD); turbidity in rainy (TUR) and dry season (SSD); forest in the catchment (FC) and in riparian zone (FR); pasture in the catchment $(\mathrm{PC})$ and in riparian zone (PR); sugar cane in catchment (CC) and in riparian zone (CR).

\begin{tabular}{|c|c|c|c|c|}
\hline Variables & Catchment & Riparian zone & & \\
\hline & Axes 1 & Axes 2 & Axes 1 & Axes 2 \\
\hline TPR & -0.20294 & -0.3178 & -0.20673 & -0.23891 \\
\hline TNR & -0.21798 & 0.2874 & -0.1553 & 0.20754 \\
\hline NO3R & 0.70485 & -0.1342 & 0.78788 & -0.27682 \\
\hline SSR & -0.66159 & -0.5082 & -0.59898 & -0.53583 \\
\hline TUR & -0.67277 & -0.4536 & -0.65632 & -0.39455 \\
\hline TPD & 0.06797 & -0.2106 & 0.10651 & -0.43362 \\
\hline TND & -0.06541 & -0.7572 & -0.20917 & -0.57093 \\
\hline NO3D & 0.81205 & -0.1472 & 0.81487 & -0.25824 \\
\hline SSD & -0.08748 & 0.7696 & 0.02384 & 0.77815 \\
\hline TUD & -0.49432 & -0.1313 & -0.42284 & -0.27605 \\
\hline $\mathrm{FC} / \mathrm{FR}$ & 0.67713 & -0.1017 & 0.88717 & -0.09978 \\
\hline $\mathrm{PC} / \mathrm{PR}$ & -0.86499 & 0.2755 & -0.90782 & 0.1646 \\
\hline $\mathrm{CC} / \mathrm{CR}$ & 0.5482 & -0.2822 & 0.41926 & -0.33173 \\
\hline Cumulative proportion & 0.2893 & 0.4435 & 0.3085 & 0.459 \\
\hline
\end{tabular}

relationship with the proportion of forest cover and a positive relationship with the proportion of pasture. The suspended sediment presented this relation but only during the rainy season. There was no relationship between total phosphorus and the proportions of land use at either of the scales evaluated.

At the catchment scale five variables were related to landscape characteristics: suspended sediment in dry season (SSD), turbidity in dry season (TUD), total phosphate in dry season (TPD) and nitrate in dry and rainy season $\left(\mathrm{NO}_{3} \mathrm{D}\right.$ and $\left.\mathrm{NO}_{3} \mathrm{R}\right)$ (Table 3). The regression analysis revealed that SSD and TUD are influenced mostly by the type of soil in the catchment, while nutrients concentration are influenced by soil type, catchment physical attributes, land use and the spatial distribution of forest. SSD presented $48 \%$ of the variation explained by nitisols (NitC) and mean DFS and the $54 \%$ of variation in TUD explained by arenosols (AreC) and ferralsols (FerC). The $86 \%$ of the variation of TPD was explained by entisols (AreC and leptosols; LepC), catchments' mean slope (SLC), pasture (PC) and largest patch index in the catchment (LPIC). Nitrate was related to landscape in both seasons. In the dry season, nitrate variation was explained $58 \%$ by LPIC and by SLC. In the rainy season, $93 \%$ of the variation in nitrate concentration was explained by FerC and LepC, ElvC and LPIC.

Correlated aquatic variables at the riparian scale were almost the same as those at the catchment scale (SSD, SSR, TUD, $\mathrm{NO}_{3} \mathrm{R}$ and $\mathrm{NO}_{3} \mathrm{D}$ ) (Table 4). Our results showed that suspended sediment and turbidity were influenced by soil type and spatial distribution of the forest and $\mathrm{NO}_{3}$ was influenced by land use, soil type, physical attributes and spatial distribution of the forest. In the dry season, suspended sediment showed $78 \%$ of the variation explained by largest patch index in the riparian zone (LPIR), Nitsols (NitR) and DFS. In the rainy season, its variation was also explained by LPIR and DFS in $54 \%$. The variation in TUD was explained $(54 \%)$ by NitR,
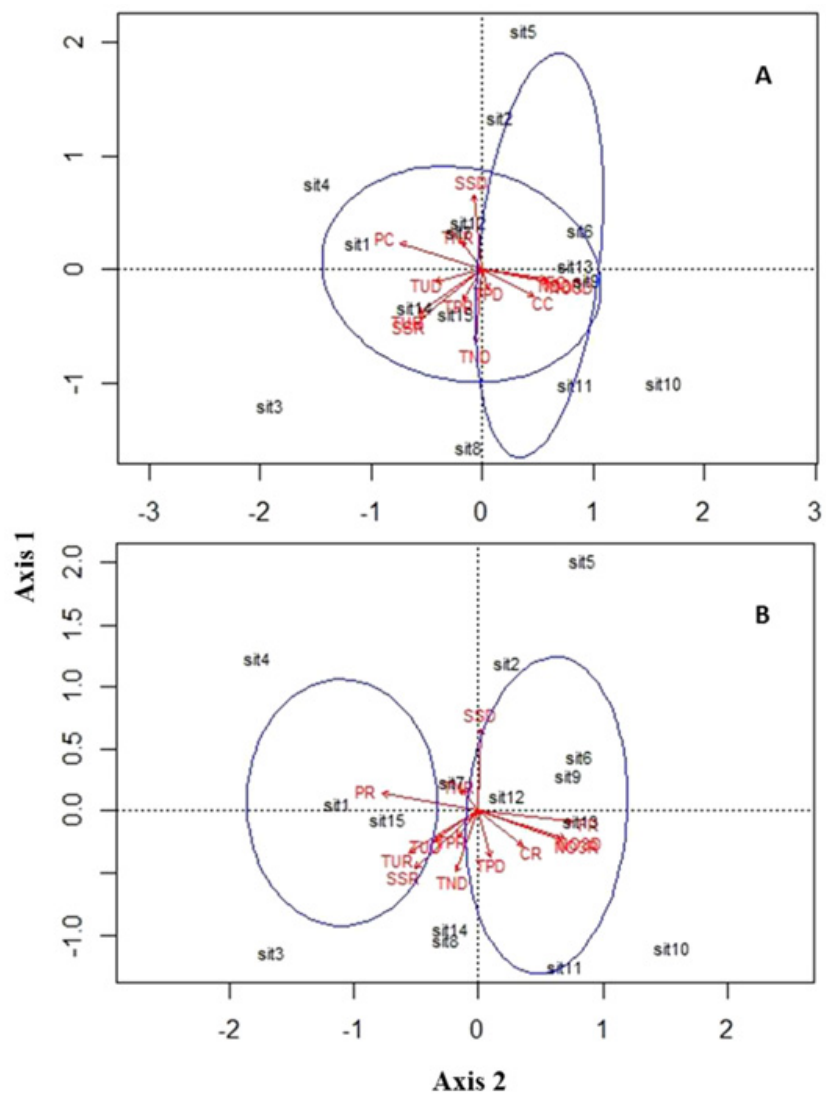

Fig. 4. Biplots for variables at catchment (A) and riparian-zone (B) scales. The ellipses (traced by standard deviation of samples scores) define the edges of each group. Suspended sediment in rainy (SSR) and dry season (SSD); nitrate in rainy $\left(\mathrm{NO}_{3} \mathrm{R}\right)$ and dry season $\left(\mathrm{NO}_{3} \mathrm{D}\right)$, total Kjeldahl nitrogen in rainy (TNR) and dry season (TND); total phosphorus in rainy (TPR) and dry season (TPD); turbidity in rainy (TUR) and dry season (TUD); forest in the catchment (FC) and riparian zone (FR); pasture in the catchment $(\mathrm{PC})$ and riparian zone $(\mathrm{PR})$; sugarcane in the catchment $(\mathrm{CC})$ and riparian zone $(\mathrm{CR})$. 
Table 3. Multiple linear regression results between water and landscape variables at the catchment scale. Suspended sediment in dry season (SSD); turbidity in dry season (TUD); total phosphate in the dry season (TPD); nitrate in dry season (NO3D) and rainy season (NO3R); pasture in the catchment (PC); mean distance of forest to stream (DFS); mean slope in the catchment (SLC); mean elevation in the catchment (ElvC); large patch index in the catchment (LPIC); nitisols in the catchment (NitC); arenosols in the catchment (AreC); ferralsols in the catchment (FerC); leptosols in the catchment (LepC).

\begin{tabular}{|c|c|c|c|c|c|}
\hline $\begin{array}{l}\text { Dependent } \\
\text { variable }\end{array}$ & & Regression & $R_{\text {adj }}^{2}$ & $P$ & $\begin{array}{l}\text { Shapiro test } \\
\text { for residuals }\end{array}$ \\
\hline$\overline{\mathrm{SSD}}$ & -3087 & 0.0399 NitC $1.736 \mathrm{e}-05$ DFS & 0.48 & 0.02 & 0.93 \\
\hline TUD & 3008 & -0.037157 AreC -0.029684 FerC & 0.54 & $<0.01$ & 0.11 \\
\hline TPD & 3724 & $\begin{array}{l}-0.519348 \text { SLC } 0.021136 \text { AreC } 0.047685 \\
\text { LepC 0.091692 LPIC } 0.055129 \text { PC }\end{array}$ & 0.86 & $<0.01$ & 0.93 \\
\hline $\mathrm{NO}_{3} \mathrm{D}$ & 6676 & 0.051130 LPIC -0.214276 SLC & 0.58 & $<0.01$ & 0.26 \\
\hline $\mathrm{NO}_{3} \mathrm{R}$ & 9610 & $\begin{array}{l}0.111616 \text { LPIC }-0.010109 \text { ElvC } 0.022222 \\
\text { FerC }-0.035004 \text { LepC }\end{array}$ & 0.93 & $<0.001$ & 0.45 \\
\hline
\end{tabular}

Table 4. Multiple linear regression results between water and landscape variables at riparian zone scale. Suspended sediment in dry season (SSD) and rainy season (SSR); turbidity in dry season (TUD); nitrate in dry season (NO3D) and rainy season (NO3R); forest in the riparian zone (FR); large patch index in the riparian zone (LPIR); mean distance of forest to stream (DFS); mean slope in the riparian zone (SLR); nitisols in the riparian zone (NitR); arenosols in the riparian zone (AreR); leptosols in the riparian zone (LepR).

\begin{tabular}{|c|c|c|c|c|c|}
\hline $\begin{array}{l}\text { Dependent } \\
\text { variable }\end{array}$ & & Regression & $R_{\text {adj }}^{2}$ & $P$ & $\begin{array}{l}\text { Shapiro test } \\
\text { for residuals }\end{array}$ \\
\hline SSR & -4.92 & -0.012644 LPIR -0.006437 DFS & 0.54 & $<0.01$ & 0.58 \\
\hline $\mathrm{NO}_{3} \mathrm{D}$ & 5.53 & 0.044599 LPIR 0.030406 LepR 0.025705 AreR - 0.256892 SLR & 0.81 & $<0.01$ & 0.33 \\
\hline $\mathrm{NO}_{3} \mathrm{R}$ & 1.61 & 0.053743 FR -0.012063 DFS & 0.72 & $<0.001$ & 0.47 \\
\hline
\end{tabular}

leptosols (LepR) and LPIR. Nitrate was related to landscape in both seasons too; best model was found at dry season, with $81 \%$ of the variation in nitrate explained by LPIR, entisols (AreR and LepR) and riparian mean slope (SLR), while in the rainy season $72 \%$ of the variation in nitrate was explained by forest (FR) and DFS.

\section{Discussion}

\section{Influence of dominant land use types}

The replacement of natural forests by agricultural lands affects hydrological processes within and across drainage basins, and consequently the physical and chemical characteristics of stream water (Ziemer and Lisle, 1998; Allan and Castillo, 2007). Therefore, these changes tend to be more apparent in catchments where there is a predominance of agricultural activities (Quinn and Stroud, 2002; Allan and Castillo, 2007). However, our results showed a more complex pattern in which the water variables did not differ between two groups, which showed contrasted levels of agricultural activity: indeed, they showed that nitrate concentrations were higher in more forested catchments for catchment scale (only in dry season) and for riparian scale (for both seasons). This could be explained at the catchment scale by the fact that the majority of the catchments studied present a mix of agriculture and forest patches. Thus, even when there are forests at the catchment scale, catchments also have a high proportion of agricultural uses, and therefore, water features may have been affected to the same extent as in locations where there is a predominance of agriculture.

At the riparian scale, we believe that two processes can explain the results: (1) the group with the highest proportion of forest has some level of fragmentation in the drainage network. Owing to places where forest coverage is fragmented act as non-point sources of pollution, this can be affecting water characteristics which are similar to what is found in deforested streams; (2) the management of sugarcane fields is so intensive (with high nutrient fertilization) that the riparian forest might not be able to retain the nitrate carried to the riparian areas by runoff or sub-surface flow (this is discussed in more detail in the next session). Consequently, the impacts of the surrounding agricultural areas are not effectively mitigated by riparian forests (Saunders et al., 2002), causing the increase of nitrate concentration in the water. For example, although sites $\mathrm{S} 10$ and $\mathrm{S} 11$ had a predominance of forest in the riparian scale, there was also a predominance of sugarcane at the catchment scale. Consequently, these catchments showed high amounts of this nutrient despite a relatively high proportion of forest cover, in the two seasons evaluated. Catchments S9 and S13 also presented high concentrations of nitrate despite do not having sugarcane fields in their landscape. However, we observed in the field that they had a chicken farm located outside of the riparian area and we also observed some waste placed closed to the riparian area and in between the boundaries of these catchments, so the nitrate might be coming from 
this. These results indicate that the configuration of forest cover and also the catchment land use may be more important to explain water variables than only the dominant land use.

\section{Relationship between catchment landscape and stream water characteristics}

Different landscape properties had an influence on the physical and chemical characteristics of stream water (Welch et al., 1998; Allan and Castillo, 2007), but in this study, topography, soil type and forest's spatial configuration were more important than land use and the water variables were more affected in the dry season. Johnson et al. (1997) and Fernandes et al. (2014) found that geomorphology, seasonality and forest position from the sampling point affected water characteristics, respectively.

At the catchment scale, we found that suspended sediment in the dry season is higher in areas with more nitisols and major DFS. Nitisols are clayey, common to rough areas, are useful for agricultural activities and susceptible to erosion (Oliveira et al., 1992). This added with increased distances of forests to streams can increase the sediments in the water. This occurs because forest act as a filter; the more distant they are from water bodies, less sediments are retained, consequently reaching the streams. Jones et al. (1999) found that stream reaches located distant from upstream forested reaches had more fine sediments and less habitat diversity than streams located close to an upstream forested reach. Also, Fernandes et al. (2014) found that stream water quality decreased as sampling sites distance increased from a forest remnant. These results show that forest position in the catchment is also an important factor to protect stream habitat and water in agricultural landscapes.

Turbidity in the dry season was negative related to arenosols and ferralsols. Arenosols are sandy, common in flat areas, with low water-holding capacity and nutrient poor, so usually non-used in agriculture activities (Oliveira et al., 1992; FAO, 2007). Ferralsols can be used to agriculture practices, but are more resistant to erosion when compared with arenosols (Oliveira et al., 1992). For this reasons the increase turbidity was not related to these characteristics.

Total phosphate in the dry season was positive related to entisols (arenosols and leptosols), pasture, largest patch index and negative related to slope. This soil types are naturally phosphate poor (Oliveira et al., 1992), indicating that major concentration of phosphate can be related to deforestation or to an external source, like the presence of pasture. Stream draining pasture areas usually contain more phosphorus concentrations than forested areas (Cooper and Thomsen, 1988; Primavesi et al., 2002; Biggs, et al., 2006), due to the use of fertilizers in the management of pasture (Smith and Monaghan, 2003; Sigua and Chase, 2014). The study area does not present a great management of the pastures and, probably, does not have current nutrient application. Despite that, forest removal increases sediment input to the water and phosphorus is often bound to sediments (Biggs, et al., 2006; Parfitt et al., 2013). This fact could be an explanation to the relation to this nutrient with pasture areas. Also, the presence of cattle itself can contribute to increase in phosphorus by animal excretion (Sigua and Chase, 2014). James et al. (2007) found $10 \%$ of total phosphorus from agriculture reaching the streams directly by cattle excrement. Its relation with major fragments can be occurring due to the mix of land uses discussed previously.

Nitrate in the dry season increased with largest patch index and decrease with slope areas. For the rainy season, its increase was also related to major fragments together with ferralsols, while the minor concentrations related to elevation and leptosols. The increase of concentrations of $\mathrm{NO}_{3}$ with values of largest patch index was contrary to our expectation, because a greater proportion of forests in the landscape should act to reduce nutrient input (Ziemer and Lisle, 1998; Allan and Castillo, 2007). However, in our study area some catchments with larger forest fragments also had a higher proportion of sugarcane plantations due to the occurrence of more fertile soils in the flat areas of the catchment (i.e., ferralsols which are usually appropriate to agriculture; Oliveira et al., 1992). Basins that drain agricultural crops have generally higher nitrogen concentrations than those draining pasture (Park et al., 2011). This can be due to the application of fertilizer to crops (Bicalho et al., 2010) that reaches water bodies through runoff (most apparent during the rainy season) and also non-retained nitrogen by tropical forests (Neill et al., 2001), which increases concentrations of nitrate in the stream water. The burning of sugarcane is also a factor that may be contributing to increase nitrate concentrations in the stream water in the sugar cane catchments. The burning of biomass in tropical regions release $\mathrm{N}$ oxides into the atmosphere, increasing $\mathrm{N}$ deposition and carrying its concentration in the water (Allan and Castillo, 2007; Martinelli and Filoso, 2008).

We found a significant relationship between landscape and nitrate in both seasons. This showed that nitrate input in the water is not restricted to runoff in the rainy season, and probably, nitrate is reaching stream water by subsurface flow in the dry season. Heathwaite and Johnes (1996) found that $40 \%$ of the total annual supply of nitrogen in agricultural catchments was derived from subsurface flow. Different from our results, Johnson et al. (1997) found a significant relationship between landscape and nitrate only in the summer (end of the rainy period); the authors suggest a hydrologic connection between the catchment and the rivers during summer that was not present in autumn.

At the riparian scale, we found some similar results. For suspended sediment in the dry season, we found that NitR, LPIR and DFS are related to higher sediments in the water. It is common the largest forest patches are located in the headwaters because these areas are steep and not useful for agriculture. On the other hand, downstream areas are flatter and suitable for agriculture, with long deforested riparian reaches. Therefore, stream margins 
erosion tend to be higher on these deforested reaches since tree roots are not protecting the margins (Allmendinger et al., 2005), thus increasing suspended sediments in the stream water. As the soil margins are largely composed of clay (nitisols), more suspended sediment is produced. In the rainy season, we found that suspended sediments increase as LPIR and DFS decreases. Despite the forest cover is closer to the stream, as LPIR decreases, less forest cover are present in the stream network (the patches are smaller) and more deforested areas are presented, causing stream margins erosion and generation of suspended sediments as explained before. This process tends to be higher in the rainy season as more runoff is produced increasing the input of sediments and also water discharge (that increase margins erosion).

Turbidity in the dry season also had an increase related to nitisols, leptosols and decreased with largest patch index. These two soils are used for agriculture practices that could favor turbid waters, probably because forests are controlling light incidence and primary productivity and also the low flow is not suspending fine sediments from the stream bottom. Conversely, the absence of forest in the pasture areas is associated with increasing the flow of particles as well increasing incidence of light and primary productivity (Quinn and Stroud, 2002; Scalley and Aide, 2003; Allan and Castillo, 2007).

$\mathrm{NO}_{3}$ showed a positive relationship with riparian forest and with largest patch index. Although riparian forests are known to act as a filter for sediments, nutrients and pesticides from surrounding agricultural areas (Wenger, 1999; Bicalho et al., 2010) and to efficiently retain nitrate (Naiman et al., 2005), the remaining forests in our study area did not appear to be efficient in reducing the amount of nitrate entering streams due to runoff and subsurface flow from sugarcane plantations. In the dry season, $\mathrm{NO}_{3}$ also showed a positive relationship with leptosols and arenosols in the riparian zone. The first one can be used for agriculture practices and the second presents a nitrate lixiviation that can explain these relationships (Oliveira et al., 1992). The negative relationship with slope is in agreement with the soil types that are common of flat areas. In the rainy season nitrate also show a negative relationship with DFS. Maybe this explains the increase relationship of nitrate in the presence of forests because, despite of its presence, the large distances of the fragments to water results in the flow of nitrate to the streams.

\section{Management implications}

Changes in land use are influenced by topographic and geologic characteristics that ultimately determine patterns of usage, occupation and the type of activity that can be developed in the area. The patterns of use and occupation seem to explain the relationship observed in this study and agree with the findings of Silva et al. (2007).

According to Saunders et al. (2002), forests will be effective in maintain the natural characteristics of the aquatic environment only when they are well conserved and moderately impacted from anthropogenic sources. This is not which occurs in the study area, where the landscape is degraded and remnant forests are highly fragmented (Valente and Vettorazzi, 2008; Paula et al., 2011). Neill et al. (2001) found higher concentrations of nitrate in forested catchments than in pasture ones in Amazon streams, and also, the use of fertilizers in sugarcane plantations in Brazil is lower compared to other more developed countries (Martinelli and Filoso, 2008). Although the use of fertilizers in sugarcane plantations in Brazil is not as intensive as in other agricultural activities, their use has recently intensified for crop production (Martinelli and Filoso, 2008). Indeed considering studies carried out in São Paulo, Silva et al. (2007) found that there was an increase in the amount of nitrate in stream water probably related to fertilizers used in the cultivation of sugarcane and other crops, which is in agreement with our results. We also observed that pasture catchments with high proportion of forest in the landscape (S5, S8, S9, S12 and S14) did not show concentrations of nitrate as high as those observed in the catchment with sugarcane plantations. Also, in the study of Gerhard (2005) developed the Corumbataí river basin, the catchments with great proportion of forest did not have major concentrations of nitrate.

These results show that degraded and highly fragmented forests may not be contributing directly toward the protection of aquatic ecosystems. The results obtained at the two spatial scales (catchment and riparian) indicate that the presence of degraded forests on both catchment and in riparian zones is not sufficient to contain the impacts of agricultural activity, reinforcing the need for the conservation and restoration of forests across both scales to exert a role of protecting and conserving the aquatic environment and water quality. Our results do not support the current modifications in the Brazilian Forest Code. The new Code decreases the extent of riparian forest areas in small farms, favoring the expansion of agricultural activities in the riparian zone. Preserving only an elevated proportion of riparian forests in the entire drainage network is not sufficient to promote water conservation in agricultural landscapes, especially when the areas are subject to agricultural effluents. Forests should be well conserved and not fragmented in the drainage network. Also, the agricultural activities in the catchment should be managed to guarantee stream and water protection. Thus, the measures adopted in the new Brazilian legislation will only further undermine the conservation of aquatic ecosystems and water resources, contributing to increase their degradation.

Acknowledgements. This project was supported by FAPESP (06/04723-3 and 08/08753-0). We would like to thank Carlos Fernando Sanches and all colleagues for help during field work and all landowners who gave us permission to work on their properties. We also thank the anonymous reviewers for their comments and suggestions which were important to the improvement of work. 


\section{References}

Allan J.D. and Castillo M.M., 2007. Stream Ecology: Structure and Function of Running Waters, Springer, New York, $436 \mathrm{p}$.

Allmendinger N.E., Pizzuto J.E., Potter N.J., Johnson T.E. and Hession W.C., 2005. The influence of riparian vegetation on stream width, eastern Pennsylvania. GSA Bull., 117, 229-243.

Bicalho S.T.T., Langenbach T., Rodrigues R.R., Correia F.V., Hagler N.A., Matallo M.B. and Luchini L.C., 2010. Herbicide distribution in soils of a riparian forest and neighboring sugar cane field. Geoderma, 158, 392-397.

Biggs T.W., Dunne T. and Muraoka T., 2006. Transport of water, solutes and nutrients from a pasture hillslope, southwestern Brazilian Amazon. Hydrol. Process., 20, 2527-2547.

Borcard D., Gillet F. and Legendre P., 2011. Numerical Ecology with R, Springer, New York, 306 p.

CEAPLA, 2008. Center for analysis and environmental planning. Environmental atlas of the Corumbataí river basin, Accessed 20 January 2011. Available online at: http:// ns.rc.unesp.br/igce/ceapla/atlas/

Cooper A.B. and Thomsen C.E., 1988. Nitrogen and phosphorus in streamwater form adjacent pasture, pine, and native forest catchments. N. Z. J. Mar. Freshw., 20, 279-291.

Crawley M.J., 2007. The R Book, John Wiley and Sons Ltd, England, 949 p.

FAO, 2007. Physical properties of tropical sandy soils: a large range of behaviours, Accessed 15 July 2014. Available online at: ftp://ftp.fao.org/docrep/fao/010/ag125e/ag125e08.pdf

Fernandes J.F., Souza A.L.T. and Tanaka M.O., 2014. Can the structure of a riparian forest remnant influence stream water quality? A tropical case study. Hydrobiologia, 724, $175-185$.

Gerhard P., 2005. Comunidades de peixes de riachos em função da paisagem da bacia do rio Corumbataí, Estado de São Paulo. Tese (Doutorado em Ecologia de Agroecossistemas) Escola Superior de Agricultura "Luiz de Queiroz", Universidade de São Paulo, Piracicaba.

Golterman H.L., Climo R.S. and Ohnstad M.A.M., 1978. Methods for Physical and Chemical Analysis of Freshwaters. I.B.P. Handbook n.8. Blackwell Scientific Publications, Oxford, 213 p.

Gregory S.V., Swanson F.J., Mckee W.A. and Cummins K.W., 1991. An ecosystem perspective of riparian zones. BioSciense, $41,540-551$.

Heathwaite A.L. and Johnes P.J., 1996. Contribution of nitrogen species and phosphorus fractions to stream water quality in agricultural catchments. Hydrol. Process., 10, 971-983.

Hunter H.M. and Walton R.S., 2008. Land-use effects on fluxes of suspended sediment, nitrogen and phosphorous from a river catchment of the Great Barrier Reef, Australia. J. Hydrol., 356, 131-146.

James E., Kleinman P., Veith T., Stedman R. and Sharpley A., 2007. Phosphorus contributions from pastured dairy cattle to streams of the Cannonsville Watershed, New York. J. Soil Water Conserv., 62, 40-47.

Johnson L.B., Richards C., Host G.E. and Arthur J.W., 1997. Landscape influences on water chemistry in Midwestern stream ecosystems. Freshw. Biol., 37, 193-208.

Jones E.B.D. III, Helfman G.S., Harper J.O. and Bolstad P.V., 1999. Effects of riparian forest removal on fish assemblages in Southern Appalachian streams. Conserv. Biol., 13, 1454-1465.

Legendre P. and Legendre L., 2000. Numerical Ecology, Elsevier, The Netherlands, $870 \mathrm{p}$.

Mackereth F.J.H., Heron J. and Talling J.F., 1978. Water Analysis: Some Revised Methods for Limnologists, Freshwater Biological Association, London, $121 \mathrm{p}$.

Martinelli L.A. and Filoso S., 2008. Expansion of sugarcane ethanol production in Brazil: environmental and social challenges. Ecol. Appl., 18, 885-898.

McGarigal K., Cushman S.A., Neel M.C. and Ene E., 2002. Fragstats: Spatial Pattern Analysis Program for Categorical Maps, University of Massachusetts, Amherst, Accessed 27 November 2009. Available online at: http://www.umass. edu/landeco/research/fragstats/fragstats.html

Naiman R.J. and Décamps H., 1997. The ecology of interfaces: riparian zones. Ann. Rev. Ecol. Syst., 28, 621-658.

Naiman R.J., Décamps H. and McClain M.E.R., 2005. Riparia: Ecology, Conservation, and Management of Streamside Communities, Elsevier, San Diego, 430 p.

Neill C., Deegan L.A., Thomas S.M. and Cerri C.C., 2001. Deforestation for pasture alters nitrogen and phosphorus in small Amazon streams. Ecol. Appl., 11, 1817-1828.

Oliveira J.B., Jacomine P.K.T. and Camargo M.N., 1992. Classes gerais de solos do Brasil: guia auxiliar para seu reconhecimento, FUNEP, Jaboticabal, 210 p.

Parfitt R.L., Frelat M., Dymond J.R., Clark M. and Roygard J., 2013. Sources of phosphorus in two subcatchments of the Manawatu River, and discussion of mitigation measures to reduce the phosphorus load. N. Z. J. Agr. Res., 56, 187-202.

Park S.R., Lee H.J., Lee S.W., Hwang S.J., Byeon M.S., Joo G.J., Jeong K.S., Kong D.S. and Kim M.C., 2011. Relationship between land use and multi-dimensional characteristics of streams and rivers at two different scales. Ann. Limnol. - Int. J. Lim., 47, S107-S116.

Paula F.R., Ferraz S.F.B., Gerhard P., Vettorazzi C.A. and Ferreira A., 2011. Large wood debris input and its influence in on channel structure in agriculture lands of southeast Brazil. Environ. Manage., 48, 750-763.

Primavesi O., Freitas A.R., Primavesi A.C. and Oliveira H.T., 2002. Water quality of the Canchim's Creek watershed in São Carlos, SP, occupied by beef and dairy cattle activities. Braz. Arch. Biol. Techn., 45, 1516-8913.

Quinn G.P. and Keough M.J., 2002. Experimental Design and Data Analysis for Biologist, University Press, Cambridge, $537 \mathrm{p}$.

Quinn J.M. and Stroud M.J., 2002. Water quality and sediment and nutrient export form New Zealand hill-land catchments of contrasting land use. N. Z. J. Mar. Freshw., 36, 409-429.

R Development Core Team, 2008. R: A Language and Environment for Statistical Computing, R Foundation for Statistical Computing, Vienna, Austria. ISBN 3-900051-00-3, Available online at: http://www.R-project.org.

Rodrigues R.R., 1999. A vegetação de Piracicaba e municípios de entorno. Circular Técnica IPEF, 189, 1-18.

Saunders D.L., Meeuwig J.J. and Vincent A.C.J., 2002. Freshwater protected areas: strategies for conservation. Conserv. Biol., 16, 30-41.

Scalley T. and Aide T.M., 2003. Riparian vegetation and stream condition in a tropical agriculture-secondary forest mosaic. Ecol. Appl., 13, 225-234. 
Sigua G.C. and Chase C.C. Jr., 2014. Groundwater phosphorus in forage-based landscape with cow-calf operation. Environ. Monit. Assess., 186, 1317-1326.

Silva D.M.L., Ometto J.P.H.B., Lobo G.A., Lima W.P., Scaranello M.A., Mazzi E. and Rocha H.R., 2007. Can land use changes alter carbon, nitrogen and major ion transport in subtropical Brazilian streams? Sci. Agric., 64, 317-324.

Smith L.C. and Monaghan R.M., 2003. Nitrogen and phosphorus losses in overland flow from a cattle-grazed pasture in Southland. N. Z. J. Agric. Res., 46, 225-237.

Storey R.G. and Cowley D.R., 1997. Recovery of three New Zealand rural streams as they pass through native forest remnants. Hydrobiologia, 353, 63-76.

Valente R.O.A. and Vettorazzi C.A., 2003. Mapeamento de uso e cobertura do solo da bacia do rio Corumbataí, SP. Circular Técnica IPEF, 196.

Valente R.O.A. and Vettorazzi C.A., 2005. Forest structure assessment in the Corumbataí river basin, SP. Sci. For., 68, $45-57$.
Valente R.O.A. and Vettorazzi C.A., 2008. Definition of priority áreas for forest conservation through the ordered weighted averaging method. Forest. Ecol. Manage., 256, 1408-1417.

Victor M.A.M., Cavalli A.C., Guillaumon J.R. and Filho R.S., 2005. Cem anos de devastação: Revisitada 30 anos depois, Ministério do Meio Ambiente, Brasília.

Welch E.B., Jacoby J.M., May C.W., 1998. Stream quality. In: Naiman R.J. and Bilby R.E. (eds), River Ecology and Management: Lessons from the Pacific Coastal Ecoregion, Springer-Verlag, New York, 69-94.

Wenger S., 1999. A Review of the Scientific Literature on Riparian Buffer Width, Extent and Vegetation, Office of Public Service \& Outreach, Athens, 59 p.

Zar J.H., 1996. Biostatistical Analyses, Prentice-Hall, New Jersey, $662 \mathrm{p}$.

Ziemer R.R. and Lisle T.E., 1998. Hydrology. In: Naiman R.J. and Bilby R.E. (eds), River Ecology and Management: Lessons from the Pacific Coastal Ecoregion, Springer, New York, 43-68. 